\title{
Helicobacter pylori infection in HIV-positive patients from the Mureş regional center
}

\author{
Nina-loana Șincu ${ }^{1 *}$, Lucia Carmen Chiriac ${ }^{1}$, Brînduşa Țilea ${ }^{1}$, Erzsebet Iringo Zaharia-Kezdi', Anca Meda Georgescu', \\ Cristina Gârbovan ${ }^{1}$, Andrea Incze ${ }^{1}$, Andreea Bodea ${ }^{2}$, Simona Bățagă ${ }^{3}$ \\ From The 9th Edition of the Scientific Days of the National Institute for Infectious Diseases Prof Dr Matei Bals \\ Bucharest, Romania. 23-25 October 2013
}

\section{Background}

Helicobacter pylori, responsible for one of the most frequent infections on the globe, was reported by several literature studies to be less frequent among patients infected with human immunodeficiency virus (HIV), especially at low levels of CD4+ T-cells. The purpose of the study was to evaluate the features of Helicobacter pylori infection in HIV-positive patients from the Mureş regional center.

\section{Methods}

We performed a retrospective, descriptive study, over a 3-year period (August 2010 - August 2013), on 63 HIVpositive patients with dyspeptic symptoms, tested for Helicobacter pylori infection in the Laboratory of Infectious Diseases, Clinical County Hospital Mureş.

\section{Results}

Seventeen (26.98\%) HIV-positive patients were coinfected with Helicobacter pylori. The average level of CD4+ T-lymphocytes was 292 cells/ $\mu \mathrm{L}$ in Helicobacter pylori-positive patients and 312 cells $/ \mu \mathrm{L}$ in Helicobacter pylori-negative ones, which did not result in a statistically significant difference regarding the level of CD4+ T-cells $(\mathrm{p}=0.8785)$.

\section{Conclusion}

Our study showed a frequency of Helicobacter pylori-HIV co-infection of $26.98 \%$ among HIV-positive patients monitored in the regional center Mureș, without statistically significant differences regarding the level of CD4+ T-cells.

\footnotetext{
* Correspondence: ninasincu@yahoo.com

'Department of Infectious Diseases, University of Medicine and Pharmacy

Tîrgu Mureş, Romania

Full list of author information is available at the end of the article
}

\section{Acknowledgement}

This paper is partly supported by the Sectorial Operational Programme Human Resources Development (SOP HRD), financed from the European Social Fund and by the Romanian Government under the contract number POSDRU 80641.

\section{Authors' details}

${ }^{1}$ Department of Infectious Diseases, University of Medicine and Pharmacy Tîrgu Mureş, Romania. ${ }^{2}$ Clinic of Infectious Diseases I, Clinical County Hospital Mureş, Romania. ${ }^{3}$ Department of Internal Medicine I, University of Medicine and Pharmacy Tîrgu Mureş, Romania.

Published: 16 December 2013

doi:10.1186/1471-2334-13-S1-P75

Cite this article as: Șincu et al: Helicobacter pylori infection in HIVpositive patients from the Mureş regional center. BMC Infectious Diseases 2013 13(Suppl 1):P75.
Submit your next manuscript to BioMed Central and take full advantage of:

- Convenient online submission

- Thorough peer review

- No space constraints or color figure charges

- Immediate publication on acceptance

- Inclusion in PubMed, CAS, Scopus and Google Scholar

- Research which is freely available for redistribution
C Biomed Central

\section{Biomed Central}

